\title{
Submucous Nerve Plexus
}

National Cancer Institute

\section{Source}

National Cancer Institute. Submucous Nerve Plexus. NCI Thesaurus. Code C52747.

A network of intersecting nerves that is derived from the superior myenteric plexus; it is located in the submucosa of the intestinal wall, and functions to both regulate gastrointestinal blood flow and control epithelial cell function. 